\title{
Association between depressive symptoms and quality of life in outpatients and inpatients with heart failure
}

\author{
Associação entre sintomas depressivos e qualidade de vida em pacientes \\ com insuficiência cardíaca ambulatoriais e hospitalizados \\ Asociación entre síntomas depresivos y calidad de vida en pacientes \\ ambulatorios y hospitalizados con insuficiencia cardíaca
}

How to cite this article:

Tinoco JMVP, Souza BPS, Oliveira SX, Oliveira JA, Mesquita ET, Cavalcanti ACD. Association between depressive symptoms and quality of life in outpatients and inpatients with heart failure. Rev Esc Enferm USP. 2021;55:e03686. doi: https://doi.org/10.1590/S1980-220X2019030903686

\author{
Juliana de Melo Vellozo Pereira \\ Tinoco $^{1}$ \\ D Beatriz Paiva e Silva de Souza ${ }^{2}$ \\ D Samara Xavier de Oliveira ${ }^{2}$ \\ D Josiana Araujo de Oliveira ${ }^{3}$ \\ Evandro Tinoco Mesquita ${ }^{1}$ \\ D Ana Carla Dantas Cavalcanti ${ }^{3}$ \\ ${ }^{1}$ Universidade Federal Fluminense, \\ Programa de Pós-Graduação em Ciências \\ Cardiovasculares, Niterói, RJ, Brazil. \\ ${ }^{2}$ Universidade Federal Fluminense, \\ Escola de Enfermagem Aurora de \\ Afonso Costa, Niterói, RJ, Brazil. \\ ${ }^{3}$ Instituto Nacional de Cardiologia, \\ Rio de Janeiro, RJ, Brazil.
}

\begin{abstract}
Objective: To analyze sociodemographic and clinical characteristics, depressive symptoms and quality of life of patients with heart failure and associate quality of life with depressive symptoms. Method: A cross-sectional study conducted with outpatients and inpatients. Sociodemographic data were collected and questionnaires were applied to assess quality of life (Minnesota Living with Heart Failure Questionnaire) and depressive symptoms (Beck Depression Inventory). Results: The sample consisted of 113 patients. Outpatients were retired $(p=0.004)$, with better education $(p=0.034)$ and higher ventricular ejection fraction $(\mathrm{p}=0.001)$. The inpatient group had greater depressive symptoms $(18.1 \pm 10$ vs $14.6 \pm 1.3 ; \mathrm{p}=0.036)$ and lower quality of life $(74.1 \pm 18.7$ vs $40.5 \pm 3.4 ; \mathrm{p}<0.001)$ than the outpatient group. Outpatients with depressive symptom scores from 18 points had worse quality of life scores in 17 of the 21 questions. Conclusion: Inpatients had worse depressive symptoms and quality of life, which was more affected in the physical dimension in those with moderate/severe depressive symptoms. Outpatients with more severe depressive symptoms had worse quality of life in all dimensions.
\end{abstract}

DESCRIPTORS

Hearth Failure; Quality of Life; Depression; Nursing Care. 


\section{INTRODUCTION}

Heart failure (HF) is a complex multisystemic clinical syndrome, leading patients to frequent hospitalizations ${ }^{(1)}$. Brazilian data point to records of approximately 200,760 thousand hospitalizations for HF in 2018, and the number of deaths of $22,332^{(2)}$.

This syndrome presents clinical signs and symptoms characterized by fatigue, dyspnea, and edema, which affect the physical capacity to perform activities of daily living, in addition to work, social and cognitive impairment, which can cause depression, anxiety and direct impact on the quality of life (QoL) of these patients ${ }^{(3)}$.

With the mission of improving the QoL of individuals with $\mathrm{HF}, \mathrm{HF}$ clinics are aimed at (outpatient) patients who need constant $\mathrm{HF}$ evolution monitoring to promote health and prevent $\mathrm{HF}$ decompensation (hospitalization) through stratification by functional class (I, II, III and IV) and disease stage (A, B, C, D).

Assessment by patient functional class is traditionally based on symptoms according to the New York Heart Association - NYHA Classification, which, despite the degree of subjectivity, has a good prognostic correlation. Functional class I refers to patients without symptoms (dyspnea) during daily activities, class II when there are symptoms triggered by daily activities, class III when symptoms are triggered by small efforts and class IV when symptoms appear in patients in rest ${ }^{(4)}$.

Disease progression stratification in stages assesses the evolution of the syndrome, as well as the prognosis and priority setting in therapy. Stage "A" includes patients at risk of developing HF, but still with no noticeable structural disease and no symptoms; Stage "B" includes patients who have acquired structural cardiac injury, but still have no symptoms of HF; Stage "C" includes patients with cardiac injury and HF symptoms; Stage "D" refers to patients with symptoms refractory to conventional treatment, and who require specialized interventions or palliative care ${ }^{(4)}$.

HF progression follow-up as well as signs and symptoms are monitored by nurses in specialized clinics that aim to promote holistic, multidisciplinary care and focused on the particularities of patients and their families. Therefore, understanding the trajectory of these patients in relation to depressive symptoms (DS) and QoL within inpatient and outpatient care is very important for defining personalized care planning.

It is known that patients with HF have worse QoL due to the progression of the syndrome. QoL is defined as the perception that individuals have of their lives and the discrepancy between expectation and the reality experienced ${ }^{(5)}$. In Brazil, an analysis of 633 patients showed that patients between 45 and 59 years old with HF had a worse QoL than elderly people without $\mathrm{HF}^{(6)}$.

Associations between DS and HF have become an increasing and common finding in literature, with relevance in clinical worsening, as well as in increased rate of hospitalizations and mortality. Moreover, the brain-heart association in HF has been studied more recently. New pathophysiological findings suggest that, in the context of this syndrome, inflammatory changes in oxidative stress, neurohumoral mechanisms and low cerebral flow may be involved ${ }^{(7)}$.

More depressed patients have a worse capacity for selfcare, being a barrier to adherence to the treatment regimen of $\mathrm{HF}^{(8)}$. A study of 682 patients with $\mathrm{HF}$ found that $36 \%$ had DS and this condition has affected between $24 \%$ to $85 \%$ of individuals ${ }^{(9)}$. Low adherence to the treatment regimen causes recurrent readmissions that generate stressful factors for patients with HF, hindering stability in their emotional, mental, social and functional life ${ }^{(3)}$.

The fact that individuals are being monitored outside hospitalization does not suggest that they present satisfactory well-being, comfort and functional capacity due to the absence of signs of disease decompensation, as biological, social and psychological factors such as depression and QoL can influence in their lives.

Since HF is associated with patients' direct biopsychosocial impairment, it is questioned in which care settings - HF clinic or hospital - individuals have worsening DS and QoL. Despite the importance of understanding these data, there are few studies that discuss this topic. Thus, studies comparing DS and QoL in patients with chronic HF in both settings are needed.

This study aimed to analyze the sociodemographic and clinical characteristics, depressive symptoms and QoL of outpatients and inpatients with $\mathrm{HF}$, in addition to associating QoL with depressive symptoms in both groups.

\section{METHOD}

\section{Study DESIGN}

This is an observational and cross-sectional study.

\section{SCENARIO}

This study was carried out in two public hospital institutions and a HF clinic in Rio de Janeiro, which estimated and associated DS and QoL of patients with HF.

The study took place in wards of two quaternary hospitals. The first specializes in cardiology and is located in the city of Rio de Janeiro, RJ. The second is a general and university hospital located in Niterói, RJ. Both institutions receive patients of the most diverse cardiological complexities, from the state's referral and counter-referral system. This study was also conducted at the Chronic Heart Failure Clinic of the university hospital.

\section{SeleCtION CRITERIA}

Patients undergoing outpatient or inpatient treatment for heart failure, with age from 18 years and history of previous chronic HF hospitalized with decompensation, regardless of etiology, were able to participate in the study. Patients with cognitive impairment, assessed through previous application of the Mini Mental State Examination - which assesses the functions of spatial, temporal orientation, immediate and evoking memory, calculation, naming language, repetition, comprehension, writing, and drawing copy - were excluded. Cognitive impairment is considered to be less than or equal 
to 24 points; in the case of less than four years of education, the cut-off point is 17 points $^{(10)}$.

\section{SAMPLE DEFINITION}

In this study, 55 inpatients with decompensated $\mathrm{HF}$ and 58 outpatients followed up in a HF clinic were selected by convenience sample, totaling 113 patients, considering the minimum statistically recommended number of 30 individuals ${ }^{(11)}$.

Non-probabilistic sampling selection occurred through consecutive selection of inpatients with decompensated chronic $\mathrm{HF}$ and outpatients during the data collection period.

The variables investigated in this study were DS and QoL, in addition to sociodemographic and clinical variables, which were age, sex, self-declared color, marital status, source of income, educational level, $\mathrm{HF}$ time, functional class of $\mathrm{HF}$ recommended by New York Heart Association, smoking, and alcoholism.

QoL was assessed by the translated and validated version of the Minnesota Living with Heart Failure Questionnaire (MLWHFQ). This consists of 21 questions regarding limitations presented by patients with HF. The last month should be the one considered to answer the questions. The total score (global score) synthesis ranges from 0 to 105 , with the lowest scores reflecting best QoL. The questions are divided into physical dimension (from 1 to 7,12 and 13), emotional dimension (from 17 to 21), and other questions (numbers 8 , $9,10,11,14,15$ and 16$)^{(12)}$.

DS were assessed by the Beck Depression Inventory (BDI), through 21 questions, with answers whose score ranges from 0 to 3. Scores are subdivided into: scores below 10 (without depression or mild depression); between 10 and 18 (mild to moderate depression); between 19 and 29 (moderate to severe depression); between 30 and 63 (severe depression) ${ }^{(13)}$.

\section{Data COllection}

Data collection was carried out between January and December 2018. Data were collected with the aid of an instrument previously prepared by the authors, with closed and open questions about patients' health history, in addition to consulting the medical record and applying $\mathrm{QoL}$ and DS questionnaires validated in $\mathrm{Brazil}^{(12-13)}$. Moreover, in inpatients, data collection was performed 72 hours after admission, to ensure that they had sufficient clinical stability to answer the questionnaires.

In order to reduce the risk of bias, a 20-hour training was carried out by the study supervisor on how to apply the questionnaires. Agreement assessment among evaluators was performed using the Kappa test, with a result of 0.8 $(p=0.003)$. Furthermore, patients were asked to answer DS and QoL questionnaires without assistance from either a caregiver or a family member. Patients were instructed to ask researchers for clarification of doubts about filling out the questionnaires or understanding any questions, if any.

\section{Data ANALYSIS AND TREATMENT}

The continuous variables DS and QoL scores, age, left ventricular ejection fraction and duration of disease were described using mean and standard deviation or median (interquartile range). The categorical variables sex, selfdeclared color, marital status, source of income, educational level, functional class, smoking, and alcoholism were described with simple frequencies and percentage.

Data organization was performed by building and synthesizing the database using the Microsoft Excel program, 2016. The data collected from the research instruments were tabulated and analyzed using the SPSS program (Statistical Package for the Social Sciences), version 20.0.

Analysis of continuous sociodemographic and clinical variables between inpatients and outpatients with HF (Table 1) was performed using the Student's t-test, once the hypothesis of normal distribution was confirmed by the Shapiro Wilk test. When the hypothesis of normal distribution was rejected, the Mann-Whitney U test was used.

The same tests (Student's or Mann-Whitney) were applied to correlate DS and QoL scores between outpatients and inpatients (Table 2) and to associate the QoL questionnaire questions in patients with scores of DS divided between values less than or equal to 18 points and greater than 18 points in HF clinic and hospitalization settings (Table 3).

The correlation between the groups studied for sociodemographic and clinical categorical variables (Table 1) and DS stratification (Table 2) occurred using the chi-square test. A $p$ value $<0.05$ was considered for all analyzes.

\section{ETHICAL ASPECTS}

This study was approved by the Research Ethics Committee of the School of Medicine/Hospital Antônio Pedro at Universidade Federal Fluminense, under Opinion 1.934.792, approved in 2017. All ethical aspects related to research with human beings were respected in accordance with Resolution 466/2012 of the Brazilian National Health Council. Patients were invited to participate in the study, and, they signed the Informed Consent Form (ICF) after reading it with the researcher.

\section{RESULTS}

The selected sample consisted of 135 patients potentially eligible to participate in the research. There was a loss of 22 patients due to discontinuation of follow-up. The final sample consisted of 113 subjects, 55 inpatients (51.3\%) and 58 outpatients $(48.6 \%)$.

Table 1 presents the sociodemographic and clinical variables of the groups studied as well as the final QoL and DS scores. Source of income $(p=0.004)$, education $(p=0.034)$ and left ventricular ejection fraction $(\mathrm{p}=0.001)$ showed statistical differences between groups.

Table 2 presents QoL and DS characterization in the total sample and in the referred groups. The prevalence of DS in the total sample was $37.2 \%$, and the QoL score was $69.8 \pm 23.3$. The QoL score of the inpatient group proved to be worse than the outpatient group $(p<0.001)$ as well as in DS assessment ( $\mathrm{p}=0.036)$.

Both groups were classified as having "mild to moderate" DS, i.e., between 10 and 18 points. However, when there 
was comparison by groups based on stratification of the DS scale, it was found that outpatients mostly present symptoms considered "mild to moderate", while inpatients had "from moderate to severe" symptoms ( $\mathrm{p}=0.024)$.

Table 3 presents inpatients and outpatients divided into two groups: one that included patients with a BDI score $<18$ points (without depressive symptoms or with mild/moderate symptoms) and another with moderate to severe DS (score $\mathrm{BDI} \geq 18$ points). When correlating the questions in the $\mathrm{QoL}$ questionnaire with the respective groups in patients seen at a HF clinic, questions number 2 to 13,17 to 21 and the total QoL score were more affected in the group with BDI score $\geq 18$ points. For inpatients, questions $3,4,9$ and 21 were also more affected in the group with moderate to severe DS.

Table 1 - Correlation of sociodemographic and clinical characteristics of the sample of inpatients and outpatients with heart failure undergoing follow-up - Niterói, RJ, Brazil, 2018.

\begin{tabular}{|c|c|c|c|c|}
\hline Variables & $\begin{array}{l}\text { Inpatient group IG } \\
\qquad(\mathrm{N}=55)\end{array}$ & $\begin{array}{l}\text { Outpatient group } \\
\text { OG }(\mathrm{N}=58)\end{array}$ & $\begin{array}{c}\text { Total } \\
(\mathrm{N}=113)\end{array}$ & $P$ value \\
\hline Age & $52.1 \pm 10.4$ & $70.4 \pm 15.0$ & $55.8 \pm 13.2$ & $0.156^{*}$ \\
\hline \multicolumn{5}{|l|}{ Sex } \\
\hline Female & $17(30.9)$ & $28(48.3)$ & $45(39.8)$ & $0.083^{* *}$ \\
\hline Male & $38(69.1)$ & $30(51.7)$ & $68(60.2)$ & \\
\hline \multicolumn{5}{|l|}{ Marital status } \\
\hline Single/widowed/divorced & $26(47.2)$ & $30(51.7)$ & $56(49.6)$ & $0.708^{* *}$ \\
\hline Married/common-law marriage & $29(52.7)$ & $28(48.3)$ & $57(50.4)$ & \\
\hline \multicolumn{5}{|l|}{ Source of income } \\
\hline Unemployed & $13(23.6)$ & $5(8.6)$ & $18(15.9)$ & $0.004^{* *}$ \\
\hline Formal/informal worker & $8(14.5)$ & $7(12.1)$ & $15(13.3)$ & \\
\hline Pensioner/retired & $34(61.8)$ & $46(79.3)$ & $80(70.8)$ & \\
\hline \multicolumn{5}{|l|}{ Education } \\
\hline Illiterate & - & $1(1.7)$ & $1(0.8)$ & $0.034^{* *}$ \\
\hline Elementary school & $28(50.9)$ & $18(31.0)$ & $46(40.7)$ & \\
\hline High school & $25(45.4)$ & $27(46.6)$ & $52(46.0)$ & \\
\hline Higher education & $2(3.6)$ & $12(20.7)$ & $14(12.3)$ & \\
\hline Left ventricular ejection fraction, $\%$ & $38.8 \pm 17.1$ & $54.4 \pm 16.9$ & $47.2 \pm 18.3$ & 0.001 \\
\hline \multicolumn{5}{|l|}{ Functional Class, NYHAll } \\
\hline I & - & $18(31.0)$ & $18(15.9)$ & - \\
\hline II & - & $33(56.8)$ & $33(29.2)$ & \\
\hline III & $41(74.5)$ & $6(10.3)$ & $47(41.6)$ & \\
\hline IV & $14(25.5)$ & $1(1.7)$ & $15(13.3)$ & \\
\hline \multicolumn{5}{|l|}{ Comorbities } \\
\hline Hypertension & $44(80)$ & $47(81.0)$ & $91(80.5)$ & 0.539 \\
\hline Diabetes Mellitus & $16(29)$ & $20(34.4)$ & $36(31.9)$ & 0.552 \\
\hline Coronary artery disease & $20(36.3)$ & $14(24.1)$ & $34(30.1)$ & 0.218 \\
\hline Smoking & $10(18.2)$ & $10(17.2)$ & $20(17.7)$ & $0.417^{* *}$ \\
\hline Alcoholism & $8(14.5)$ & $15(25.9)$ & $23(20.4)$ & $0.517^{* *}$ \\
\hline
\end{tabular}

Legend: *Student's t-test; ${ }^{* *}$ Chi-square test; IMann-Whitney $U$ test; $॥$ Comparison test not performed between groups, as the functional class is affected in episodes of HF decompensation.

Note: $\mathrm{N}=113$. 
Table 2 - Quality of life and depressive symptoms of patients with heart failure - Niterói, RJ, Brazil, 2018.

\begin{tabular}{|c|c|c|c|}
\hline Variables & Inpatient group IG (N=55) & $\begin{array}{l}\text { Outpatient group } \\
\text { OG }(N=58)\end{array}$ & P value \\
\hline Total QoL score & $74.1 \pm 18.7$ & $40.5 \pm 3.4$ & $\mathrm{p}<0.001$ \\
\hline $\begin{array}{l}\text { Patients with depressive symptoms } \\
\text { (score } \geq 18 \text { points) }\end{array}$ & $23(39.6)$ & $19(32.7)$ & 0.337 \\
\hline Total DS score & $18.1 \pm 10.5$ & $14.6 \pm 1.3$ & 0.0361 \\
\hline \multicolumn{4}{|l|}{ DS stratification } \\
\hline No depression or mild depression & $7(12.7)$ & $22(37.9)$ & \\
\hline Mild to moderate depression & $26(45.5)$ & $19(32.7)$ & $0.024^{* *}$ \\
\hline Moderate to severe depression & $15(27.2)$ & $12(20.7)$ & \\
\hline Severe depression & $7(12.7)$ & $5(8.6)$ & \\
\hline
\end{tabular}

Legend: ${ }^{* *}$ Chi-square test; IMann-Whitney $U$ test.

Note: $\mathrm{N}=113$.

Table 3 - Correlation between quality of life and scores of depressive symptoms in inpatients and outpatients with heart failure undergoing follow-up - Niterói, RJ, Brazil, 2018.

\begin{tabular}{|c|c|c|c|c|c|c|}
\hline \multirow{2}{*}{ Questions - QoL questionnaire } & \multicolumn{3}{|c|}{$\begin{array}{l}\text { Inpatient group } \\
\text { IG }(\mathrm{N}=55)\end{array}$} & \multicolumn{3}{|c|}{$\begin{array}{l}\text { Outpatient group } \\
\text { OG }(N=58)\end{array}$} \\
\hline & $\begin{array}{c}\text { BDI }<18 \\
(\mathrm{~N}=32)\end{array}$ & $\begin{array}{c}B D I \geq 18 \\
(N=23)\end{array}$ & p-value* & $\begin{array}{c}\text { BDI }<18 \\
(\mathrm{~N}=39)\end{array}$ & $\begin{array}{c}\text { BDI } \geq 18 \\
(\mathrm{~N}=19)\end{array}$ & p-value \\
\hline $\begin{array}{l}\text { 1. Causing swelling in your ankles or } \\
\text { legs? }\end{array}$ & $0(0-3.0)$ & $3.0(0-5.0)$ & $0.083 \mid$ & $0(0-3.0)$ & $0(3.0-5.0)$ & 0.60 \\
\hline $\begin{array}{l}\text { 2. Making you sit or lie down to rest } \\
\text { during the day? }\end{array}$ & $3.9 \pm 1.3$ & $4.4 \pm 0.8$ & 0.73 & $1.0(0-3.0)$ & $3.5(2.75-5.0)$ & $p>0.001$ \\
\hline $\begin{array}{l}\text { 3. Making your walking about or } \\
\text { climbing stairs difficult? }\end{array}$ & $4.2 \pm 1.2$ & $4.8 \pm 0.9$ & 0.016 & $2.0(0-3.0)$ & $4.0(3.0-5.0)$ & $\mathrm{p}>0.001$ \\
\hline 4. Making your housework difficult? & $3.5 \pm 1.7$ & $4.3 \pm 0.9$ & 0.027 & $1.0(0-3.0)$ & $4.0(3.0-5.0)$ & $\mathrm{p}>0.001$ \\
\hline $\begin{array}{l}\text { 5. Making your going places away } \\
\text { from home difficult? }\end{array}$ & $4.0 \pm 1.3$ & $4.3 \pm 1.3$ & 0.408 & $1.0(0-3.0)$ & $3.5(2.0-5.0)$ & 0.001 \\
\hline $\begin{array}{l}\text { 6. Making your sleeping well at night } \\
\text { difficult? }\end{array}$ & $3.9 \pm 1.5$ & $4.2 \pm 1.1$ & 0.463 & $0(0-2.0)$ & $3.0(2.0-4.25)$ & 0.003 \\
\hline $\begin{array}{l}\text { 7. Making your relating to or doing } \\
\text { things with your friends or family } \\
\text { difficult? }\end{array}$ & $3.2 \pm 2.1$ & $3.3 \pm 2.1$ & 0.475 & 0 & $3.0(0-4.0)$ & $p>0.001$ \\
\hline $\begin{array}{l}\text { 8. Making your working to earn a } \\
\text { living difficult? }\end{array}$ & $3.3 \pm 2.1$ & $3.9 \pm 1.9$ & 0.310 & $0(0-3.0)$ & $2.0(0-5.0)$ & 0.087 \\
\hline $\begin{array}{l}\text { 9. Making your recreational pastimes, } \\
\text { sports or hobbies difficult? }\end{array}$ & $3.0 \pm 2.1$ & $4.1 \pm 1.4$ & 0.027 & $0(0-3.0)$ & $4.0(0.75-5.0)$ & 0.006 \\
\hline $\begin{array}{l}\text { 10. Making your sexual activities } \\
\text { difficult? }\end{array}$ & $3.0 \pm 2.0$ & $3.5 \pm 2.0$ & 0.319 & $1.0(0-3.0)$ & $4.0(0-5.0)$ & 0.138 \\
\hline $\begin{array}{l}\text { 11. Making you eat less the food you } \\
\text { like? }\end{array}$ & $4.1 \pm 1.3$ & $3.3 \pm 1.9$ & 0.082 & $0(2.0-5.0)$ & $4.5(1.0-5.0)$ & 0.022 \\
\hline 12. Making you short of breath? & $4.5 \pm 0.9$ & $4.5 \pm 0.8$ & 0.991 & $1.0(0-3.0)$ & $4.0(3.0-5.0)$ & $\mathrm{p}>0.001$ \\
\hline $\begin{array}{l}\text { 13. Making you tired, fatigued, or low } \\
\text { on energy? }\end{array}$ & $4.4 \pm 1.1$ & $4.6 \pm 1.1$ & 0.592 & $2.0(0-3.0)$ & $4.5(3.0-5.0)$ & $\mathrm{p}>0.001$ \\
\hline 14. Making you stay in a hospital? & $4.2 \pm 1.3$ & $4.2 \pm 1.4$ & 0.977 & 0 & $0(0-0.25)$ & 0.093 \\
\hline $\begin{array}{l}\text { 15. Costing you money for medical } \\
\text { care? }\end{array}$ & $3.4 \pm 1.8$ & $3.5 \pm 1.7$ & 0.819 & $3.0(0-4.0)$ & $4.5(2.0-5.0)$ & 0.071 \\
\hline $\begin{array}{l}\text { 16. Giving you side effects from } \\
\text { treatments? }\end{array}$ & $2.0(0-3.0)$ & $1.0(0-4.0)$ & $0.859 \mid$ & $0(0-2.0)$ & $0(0-1.0)$ & 0.564 \\
\hline $\begin{array}{l}\text { 17. Making you feel you are a burden } \\
\text { to your family or friends? }\end{array}$ & $3.0(0-5.0)$ & $3.0(0-5.0)$ & $0.804 \mid$ & 0 & $1.0(0-5.0)$ & 0.002 \\
\hline $\begin{array}{l}\text { 18. Making you feel a loss of self- } \\
\text { control in your life? }\end{array}$ & $5.0(4.0-5.0)$ & $5.0-(3.0-5.0)$ & 0.5521 & 0 & $3.0(0-4.25)$ & $\mathrm{p}>0.001$ \\
\hline 19. Making you worry? & $4.1 \pm 1.3$ & $4.1 \pm 1.5$ & 0.885 & $2.0(0-3.0)$ & $5.0(3.0-5.0)$ & 0.001 \\
\hline $\begin{array}{l}\text { 20. Making it difficult for you to } \\
\text { concentrate or remember things? }\end{array}$ & $1.0(0-3.0)$ & $3.0(1.0-5.0)$ & 0.9521 & $1.0(0-3.0)$ & $4.0(0-5.0)$ & 0.017 \\
\hline
\end{tabular}




\begin{tabular}{|c|c|c|c|c|c|c|}
\hline \multirow{2}{*}{ Questions - QoL questionnaire } & \multicolumn{3}{|c|}{$\begin{array}{l}\text { Inpatient group } \\
\text { IG }(N=55)\end{array}$} & \multicolumn{3}{|c|}{$\begin{array}{l}\text { Outpatient group } \\
\text { OG }(N=58)\end{array}$} \\
\hline & $\begin{array}{c}\text { BDI < } 18 \\
(N=32)\end{array}$ & $\begin{array}{c}\text { BDI } \geq 18 \\
(N=23)\end{array}$ & p-value* & $\begin{array}{c}\text { BDI }<18 \\
(N=39)\end{array}$ & $\begin{array}{c}\text { BDI } \geq 18 \\
(N=19)\end{array}$ & p-value \\
\hline 21. Making you feel depressed? & $2.0(0-3.0)$ & $4.0(1.0-5.0)$ & $0.011 \mid$ & $0(0-1.0)$ & $3.5(0-5.0)$ & 0.001 \\
\hline QoL total score & $73.4 \pm 18.4$ & $79.6 \pm 18.5$ & 0.106 & $26(12.0-46.0)$ & $65.5(54.7-75.2)$ & $\mathrm{p}>0.001$ \\
\hline
\end{tabular}

Legend: *Student's t-test; IMann-Whitney $U$ test.

Note: $\mathrm{N}=113$.

\section{DISCUSSION}

The present study estimated populations of patients with DS for the first time, associating them with different dimensions of the QoL of patients with HF from the Unified Health System (SUS - Sistema Unico de Saúde) during hospitalization and in a specialized clinic.

Concerning sociodemographic and clinical characteristics, significant differences between groups, retirees or pensioners were more prevalent in patients from HF clinics $(\mathrm{p}=0.004)$. The education of outpatients was higher $(\mathrm{p}=0.034)$ as well as left ventricular ejection fraction $(\mathrm{p}=0.001)$. It was expected to find inpatients with reduced left ventricular ejection fraction, since they were in a situation of decompensation. This data is consistent with a previous Brazilian epidemiological study on the clinical aspects of HF during hospitalization (left ventricular ejection fraction $=38.8 \pm 16.5)^{(14)}$.

As for education, a cross-sectional Brazilian study with a sample of 84 outpatients with HF followed up showed that the predominant educational profile is complete elementary school (56\%), supporting the sample of inpatients in this study ${ }^{(15)}$. Another national study with a sample of 91 patients showed that individuals undergoing outpatient HF treatment have the same characteristics $(83.5 \%$ retired and with education completed within four years) ${ }^{(16)}$.

Low-education patients tend to show an increase in the number of readmissions, since, the higher the level of education, it is assumed that there is a better understanding of the care prescribed after hospital discharge ${ }^{(16)}$. In this regard, the presence of a caregiver is important so that there is better clarification about pharmacological and nonpharmacological treatment.

Concerning source of income, the condition of a retired person or pensioner is a reality for patients with HF, which is progressively impaired in relation to functional capacity, even when they are economically active. Not working is an important factor for increasing risk of depression, so it is currently recommended that return to work, within the favorable health conditions presented by patients, occurs as early as possible ${ }^{(17)}$.

Inpatients had a higher prevalence of DS. Of these, those who had DS from 18 points had affected QoL in relation to walking/climbing stairs, housework, leisure activities and feeling depressed. Outpatients with DS in the same condition ( $\geq 18$ points), on the other hand, had their QoL most affected in all dimensions and the worst total scores.

Objectively identifying DS from the application of questionnaires in patients with $\mathrm{HF}$ is a good practice by health professionals. The Beck Depression Inventory, used in this study, is considered a gold standard for this assessment ${ }^{(18)}$.
Studies involving pharmacological treatment in patients with $\mathrm{HF}$ and depression show no impact; therefore, nonpharmacological approaches are necessary, as well as an understanding of the origin and prevalence of DS in different settings of $\mathrm{HF}$, as well as the mechanisms involved ${ }^{(8)}$.

A Brazilian study that assessed a population of 76 patients treated at a specialized HF clinic found that $67.1 \%$ had $\mathrm{DS}^{(18)}$. Another national study found in 81 patients with $\mathrm{HF}$ in primary care that the mean DS score was 13.6 \pm 10.4 and that $32 \%$ of the sample had moderate to severe symptoms ${ }^{(19)}$. An international study showed that the DS score of patients had a mean of 19.4 (mild to moderate) ${ }^{(20)}$.

Such findings demonstrate variability in the prevalence of these scores in previous studies in older patients, most of them female. In the present study, the prevalence of DS was similar to that shown in the literature, but more evident in inpatients and without association with sex and age.

In this study, the DS identified in both groups as "mild to moderate" may be related to the fact that patients are uncomfortable answering questions related to negative feelings ${ }^{(21)}$. Patients are also uncomfortable with the stigma of the word "depression", which provides a negative or pejorative understanding of this condition, leading individuals to feel fearful of being discredited, misunderstood, devalued and stigmatized ${ }^{(22)}$. The brain/mind and heart interaction has been recognized and better understood in the past two decades. Inflammatory aspects, low cardiac output and multiple comorbidities in patients with HF affect not only cognitive aspects, but also interfere with mental aspects, with DS being one of the manifestations. Additionally, medication used to treat $\mathrm{HF}$ and the comorbidities present in this group of patients, in addition to causing delirium in the context of hospitalizations, can cause or worsen DS. All of these factors may be associated with the higher DS rates found in hospitalized HF patients, who are subjected to a greater number of medications and exposed to environmental and psycho-emotional factors that cause depression in HF.

There is a complex interaction between HF, cognitive limitation and depression. Patients with HF have worse cognitive impairment, both in young and older people, when compared to individuals without significant comorbidities $^{(7)}$. However, once patients are hospitalized, symptoms of hypoactive delirium may also occur, through changes in individuals' routine, prolonged confinement and changes in medication regimen. Patients in this condition can be misdiagnosed with depression ${ }^{(7)}$. Thus, the investigation of DS in these patients must be valued and detailed in order to enable the correct treatment with a multidisciplinary team. 
Current European HF guidelines point to DS as a symptom of $\mathrm{HF}$ and also as a comorbidity ${ }^{(23)}$. American guidelines show DS as one of the ten most common chronic conditions of HF, but without directing the approach to patients ${ }^{(24)}$. The current Brazilian HF guideline recommends, to improve QoL, specific pharmacological treatment, cognitive-behavioral therapy and physical activity ${ }^{(8)}$. It is noted that there is no scientific evidence on the reduction of cardiovascular events in HF and DS with specific pharmacological therapy, and sertraline and citalopram, medications considered safe, must be prescribed by a specialized professional ${ }^{(8)}$. There is also no differentiated approach between hospitalized patients and follow-up in HF clinics. From QoL correlation by DS stratification, two different situations were observed. In hospitalized patients, the physical dimension of $\mathrm{QoL}$ was more affected in those with more severe DS. In the HF clinic setting, all QoL dimensions were affected in the most depressed.

More depressed inpatients with HF exacerbate the worsening of their symptoms, especially the state of fatigue and dyspnea. Collaborative factors include fear of dying, social isolation, changes in routine and invasive procedures. In this context, it is suggested to develop a care plan for patients who are developing DS on admission as well as to avoid interrupting the pharmacological treatment of those already clinically diagnosed with depression. Regarding functional aspect, interventions in order to avoid worsening of sarcopenia, improve motor and respiratory function, with respiratory training, stimulation of early walking and promotion of selfcare independence should be considered.

Moreover, interventions in inpatients with HF that include their participation and family in decision-making regarding hospital treatment, personalized emotional support, identification of negative thoughts, cognitive distortions, and understanding and recognition of readiness for resilience seem to better empower individuals in the challenge against $\mathrm{DS}^{(25-26)}$. In relation to multidisciplinary clinical practice in HF clinics, personalizing care is a support point to initiate a collaborative approach in which patients participate actively, with the joint establishment of goals for their lives. Understanding psychosocial issues individually and establishing bridges between professionals, family and caregiver are central to the construction of a personalized approach in individuals identified with the worst DS in the most affected QoL dimensions. A Brazilian study conducted on patients with outpatient HF found that the QoL dimensions most affected by this group were physical, emotional and social, respectively. And $60 \%$ of patients considered their health status worse when compared to a year ago ${ }^{(27)}$.

Previous studies indicate associations between DS and QoL. A prospective analysis with 117 patients with HF revealed that DS were associated with worsening $\mathrm{QoL}$ and increased risk of cognitive impairment ${ }^{(28)}$. Another study assessed in 147 patients with $\mathrm{HF}$ a positive correlation between the scores of DS and QoL questionnaires, indicating that patients with more DS had low $\mathrm{QoL}^{(29)}$. Another research with 200 patients with HF followed up on an outpatient basis estimated that those with the worst rates of anxiety and depression were predictors of the worst QoL scores in physical and mental dimensions ${ }^{(30)}$. However, the QoL questionnaire used in the present study presents questions related to psychological and affective situations, which are interconnected with DS. Thus, it is still questionable whether the worsening of QoL leads to a higher intensity of DS or vice versa. The results of this study reflect the need of questioning by the multidisciplinary team where the failure in relation to caring for patients with HF may be so that they have high QoL and DS scores, since they can influence the worsening of treatment adherence and readmission. Thus, a possibility to promote biopsychosocial well-being in both settings may be in the hospital to home care transition and vice versa, with adequate and personalized support for reintegration of patients into their daily lives after discharge, as recommended by the current Brazilian HF guideline ${ }^{(4)}$. One can cite as a limitation of this study the fact of presenting a small-size convenience sample ( $n=113$ patients), the cross-sectional character, which does not allow to verify the relationship between cause and effect, as well as the fact that patients were not the same both in hospitalization and in the HF clinic.

\section{CONCLUSION}

The present study, when comparing samples from patients with HF, identified a higher prevalence of DS, particularly during hospitalization. QoL was more affected in the physical dimension in inpatients with moderate to severe DS. In patients followed up at the HF clinic, the most depressed individuals had worse QoL in all dimensions studied.

One suggests prospective cohort studies in patients with $\mathrm{HF}$, with larger samples, to analyze the factors that predict the worsening of $\mathrm{QoL}$ and DS in this clientele over time.

Systematic screening with the aid of questionnaires validated in HF in relation to DS and QoL is important to identify this group of patients and to seek a better strategy for early approach to functional and psycho-emotional aspects, with promotion of adherence to HF pharmacological and nonpharmacological treatment. Estimating the prevalence of DS and QoL is essential so that the effects on interventions are measured and that individuals who do not respond to the multifaceted approaches proposed in HF treatment are referred to a specialized approach.

\section{RESUMO}

Objetivo: Analisar as características sociodemográficas e clínicas, sintomas depressivos e qualidade de vida de pacientes com insuficiência cardíaca e associar a qualidade de vida com os sintomas depressivos. Método: Estudo transversal, realizado com pacientes ambulatoriais e hospitalizados. Foram coletados dados sociodemográficos e aplicados questionários para avaliação da qualidade de vida (Minnesota Living with Heart Failure Questionnaire) e sintomas depressivos (Inventário de Depressão de Beck). Resultados: A amostra foi composta por 113 pacientes. Os ambulatoriais são aposentados $(\mathrm{p}=0,004)$, com melhor escolaridade $(\mathrm{p}=0,034)$ e maior fração de ejeção ventricular ( $p=0,001)$. O grupo hospitalizado teve maiores sintomas depressivos $(18,1 \pm 10$ vs $14,6 \pm 1,3 ; p=0,036)$ e menor qualidade de vida $(74,1 \pm 18,7$ vs 40,5 $\pm 3,4 ; \mathrm{p}<0,001)$ do que o grupo ambulatorial. Pacientes ambulatoriais com escores de sintomas depressivos a partir de 
18 pontos apresentaram piores escores de qualidade de vida em 17 das 21 questões. Conclusão: Pacientes hospitalizados tiveram piores sintomas depressivos e qualidade de vida, sendo esta mais afetada na dimensão física naqueles com sintomas depressivos moderados/ graves. Pacientes ambulatoriais com sintomas depressivos mais severos tiveram pior qualidade de vida em todas as dimensões.

\section{DESCRITORES}

Insuficiência Cardíaca; Qualidade de vida; Depressão; Cuidados de Enfermagem.

\section{RESUMEN}

Objetivo: Analizar las características sociodemográficas y clínicas, los síntomas depresivos y la calidad de vida de los pacientes con insuficiencia cardíaca y asociar la calidad de vida con los síntomas depresivos. Método: Estudio transversal, realizado con pacientes ambulatorios y hospitalizados. Se recolectaron datos sociodemográficos y se aplicaron cuestionarios para evaluar la calidad de vida (Minnesota Living with Heart Failure Questionnaire) y síntomas depresivos (Inventario de Depresión de Beck). Resultados: La muestra estuvo conformada por 113 pacientes. Los pacientes ambulatorios son jubilados $(p=0,004)$, con mejor escolaridad ( $p=0,034)$ y mayor fracción de eyección ventricular $(\mathrm{p}=0,001)$. El grupo hospitalizado presentó mayores síntomas depresivos $(18,1 \pm 10 \mathrm{vs} 14,6 \pm 1,3 ; \mathrm{p}=0,036)$ y menor calidad de vida $(74,1 \pm 18,7$ vs $40,5 \pm 3,4 ; \mathrm{p}<0,001)$ que el grupo ambulatorio. Los pacientes ambulatorios con puntuaciones de síntomas depresivos de 18 puntos tuvieron las peores puntuaciones de calidad de vida en 17 de las 21 preguntas. Conclusión: Los pacientes hospitalizados presentaron peor sintomatología depresiva y calidad de vida, la cual fue más afectada en la dimensión física en aquellos con sintomatología depresiva moderada/severa. Los pacientes ambulatorios con síntomas depresivos más graves tenían peor calidad de vida en todas las dimensiones.

\section{DESCRIPTORES}

Insuficiencia Cardíaca; Calidad de Vida; Depresión; Atención de Enfermería.

\section{REFERENCES}

1. Souza MC, Santos SR, Holmes ES, Pereira WDF, Arruda AJCG, Fonseca LCT, et al. Contributions of nurses in health education of patients with heart failure. Int Arch Med. 2016;9(387):1-7. doi: http://dx.doi.org/10.3823/2258

2. Brasil. Ministério da Saúde. DATASUS. Informações de Saúde. Epidemiológicas e morbidade [Internet]. Brasília; 2019 [citado 2019 jul. 17]. Disponível em: http://www2.datasus.gov.br/DATASUS/index.php?area=0203

3. Saccomann ICRS, Cintra FA, Gallani MCBJ. Factors associated with beliefs about adherence to non pharmacological treatment of patients with heart failure. Rev Esc Enferm USP. 2014;48(1):18-24. doi: http://dx.doi.org/10.1590/S0080-623420140000100002

4. Comitê Coordenador da Diretriz de Insuficiência Cardíaca. Diretriz Brasileira de Insuficiência Cardíaca Crônica e Aguda. Arq Bras Cardiol. 2018;111(3):436-539. doi: http://dx.doi.org/10.5935/abc.20180190

5. World Health Organization. The World Health Organization Quality of Life assessment (WHOQOL): position paper from the World Health Organization. Soc Sci Med. 1995;41(10):1403-9. doi: 10.1016/0277-9536(95)00112-k

6. Jorge AJL, Rosa MLG, Correia DMS, Martins WA, Ceron DMM, Coelho LCF, et al. Evaluation of quality of life in patients with and without heart failure in primary care. Arq Bras Cardiol. 2017;109(3):248-52. doi: http://dx.doi.org/10.5935/abc.20170123

7. Havakuk O, King KS, Grazette L, Yoon AJ, Fong M, Bregman N, et al. Heart failure-induced brain injury. J Am Coll Cardiol. 2017;69(12):160916. doi: https://doi.org/10.1016/j.jacc.2017.01.022

8. Freedland KE, Carney RM, Rich MW, Steinmeyer BC, Rubin EH. Cognitive behavior therapy for depression and self-care in heart failure patients: a randomized clinical trial. JAMA Intern Med. 2015;175(11):1773-82. doi: https://doi.org/10.1001/jamainternmed.2015.5220

9. Freedland KE, Carney RM, Rich MW, Steinmeyer BC, Skala JA, Dávila Román VG. Depression and multiple rehospitalizations in patients with heart failure. Clin Cardiol. 2016;39(5):257-62. doi: https://doi.org/10.1002/clc.22520

10. Lourenço RA, Veras RP. Mini-Exame do Estado Mental: características psicométricas em idosos ambulatoriais. Rev Saúde Pública. 2006 40(4):712-9. doi: https://doi.org/10.1590/S0034-89102006000500023

11. Miot HA. Tamanho da amostra em estudos clínicos e experimentais. J Vasc Bras. 2011;10(4):275-8. doi: http://dx.doi.org/10.1590/S167754492011000400001

12. Carvalho VO, Guimarães GV, Carrara D, Bacal F, Bocchi EA. Validação da versão em português do Minnesota Living with Heart Failure Questionnaire. Arq Bras Cardiol. 2009;93(1):39-44. doi: http://dx.doi.org/10.1590/S0066-782X2009000700008

13. Gomes-Oliveira MH, Gorenstein C, Lotufo Neto F, Andrade LH, Wang YP. Validation of the Brazilian Portuguese version of the Beck Depression Inventory-II in a community sample. Rev Bras Psiquiatr. 2012;34(4):389-94. doi: https://dx.doi.org/10.1016/j.rbp.2012.03.005

14. Albuquerque DC, Souza Neto JD, Bacal F, Rohde LEP, Bernardez-Pereira S, Berwanger O, et al. I Registro Brasileiro de Insuficiência Cardíaca - Aspectos Clínicos, Qualidade Assistencial e Desfechos Hospitalares. Arq Bras Cardiol. 2015;104(6):433-442. doi: https://doi. org/10.5935/abc.20150031

15. Cavalcante LM, Lima FET, Custodio IL, Oliveira SKP, Meneses LST, Oliveira ASS, et al. Influência de características sociodemográficas no autocuidado de pessoas com insuficiência cardíaca. Rev Bras Enferm. 2018 ;71 Supl. 6:2604-11. doi: https://doi.org/10.1590/00347167-2017-0480

16. Almeida GAS, Teixeira JBA, Barichello E, Barbosa MH. Perfil de saúde de pacientes acometidos por insuficiência cardíaca. Esc Anna Nery. 2013;17(2):328-35. doi: https://doi.org/10.1590/S1414-81452013000200018

17. Sousa MM, Oliveira JS, Soares MJGO, Bezerra SMMS, Araújo AA, Oliveira SHS. Associação das condições sociais e clínicas à qualidade de vida de pacientes com insuficiência cardíaca. Rev Gaúcha Enferm. 2017;38(2):e65885. doi: http://dx.doi. org/10.1590/19831447.2017.02.65885

18. Guerra TRB, Venancio ICD, Pinheiro DMM, Mendlowicz MV, Cavalcanti ACD, Mesquita ET. Methods of screening for depression in outpatients with heart failure. Int J Cardiovasc Sci. 2018;31(4):414-21. doi: http://dx.doi.org/10.5935/2359-4802.20180037 
19. Morais ER, Carvalho CS, Euqueres L, Viana FP, Fantinati AM, Rassi S. Qualidade de vida e sintomas de depressão e ansiedade em portadores de insuficiência cardíaca crônica. Rev EVS (Goiânia). 2018;45(1):71-9. doi: 10.18224/evs.v45i1.6286

20. Chen TY, Kao CW, Cheng SM, Chang YC. Uncertainty and depressive symptoms as mediators of quality of life in patients with heart failure. PLoS One. 2018. 14;13(11):e0205953. doi: https://doi.org/10.1371/journal.pone.0205953

21. Sokoreli I, de Vries JJ, Riistama JM, Pauws SC, Steyerberg EW, Tesanovic A, et al. Depression as an independent prognostic factor for all-cause mortality after a hospital admission for worsening heart failure. Int J Cardiol. 2016;220:202-7. doi: https://10.1016/j. ijcard.2016.06.068

22. Pena FM, Amorim A, Fassbender C, Oliveira RFJ, Faria CAC. Insuficiência cardíaca e depressão: uma associação com desfechos negativos. Insuf Card [Internet]. 2011 [citado 2019 jul. 17];6(4):170-8. Disponível em: http://www.scielo.org.ar/scielo.php?script=sci_arttext\&pid $=$ S1852-38622011000400004

23. Ponikowski P, Voors AA, Anker SD, Bueno H, Cleland JGF, Coats AJS, et al. 2016 ESC Guidelines for the diagnosis and treatment of acute and chronic heart failure: The Task Force for the diagnosis and treatment of acute and chronic heart failure of the European Society of Cardiology (ESC) Developed with the special contribution of the Heart Failure Association (HFA) of the ESC. Eur Heart J. 2016;37(27):2129200. doi: https://doi.org/10.1093/eurheartj/ehw128

24. Yancy CW, Jessup M, Bozkurt B, Butler J, Casey Jr DE, Colvin MM, et al. 2017 ACC/AHA/HFSA Focused Update of the 2013 ACCF/AHA Guideline for the Management of Heart Failure: a report of the American College of Cardiology/ American Heart Association Task Force on Clinical Practice Guidelines and the Heart Failure Society of America. Circulation. 2017;136(6):e137-61. doi: https://doi.org/10.1161/ CIR.0000000000000509

25. Mendes AMOC, Eufrásio MLP. Análise compreensiva de uma intervenção na ansiedade e depressão em doentes hospitalizados com insuficiência cardíaca. Rev Enf Ref. 2013;serlII(11):29-35. doi: http://dx.doi.org/10.12707/RIII1305

26. Queiroz MEG, Nelsen MLFN. Atenção integrada à pessoa com insuficiência cardíaca na perspectiva terapêutico ocupacional e psicológica: um relato de experiência. REFACS Online. 2018;6(1):123-9. doi: https://doi.org/10.18554/refacs.v6i1.2374

27. Soares DA, Toledo JAS, Santos LF, Lima RMB, Galdeano LE. Qualidade de vida de portadores de insuficiência cardíaca. Acta Paul Enferm. 2008;21(2):243-8. doi: http://doi.org/10.1590/S0103-21002008000200002

28. Loo DWY, Jiang Y, Koh KWL, Lim FP, Wang W. Self-efficacy and depression predicting health-related quality of life of outpatients with chronic heart failure in Singapore. Appl Nurs Res. 2016;32:148-55. doi: https://doi.org/10.1016/j.apnr.2016.07.007

29. Kim J, Hwang SY, Heo S, Shin MS, Kim SH. Predicted relationships between cognitive function, depressive symptoms, self-care adequacy, and health related quality of life and major events among patients with heart failure. Eur J Cardio Vasc Nurs. 2019;18(5):418-26. doi: https://doi.org/10.1177/1474515119840877

30. AbuRuz ME. Anxiety and depression predicted quality of life among patients with heart failure. J Multidiscip Healthc. 2018;11:367-73. doi: https://doi.org/10.2147/JMDH.S170327 